\title{
The partition of salts (i) between two immiscible solution phases and (ii) between the solid salt phase and its saturated salt solution
}

\author{
Fritz Scholz $^{1}$ (D) $\cdot$ Heike Kahlert $^{1} \cdot$ Richard Thede $^{1}$
}

Received: 17 December 2019/Accepted: 2 March 2020/Published online: 24 April 2020

(C) The Author(s) 2020

\begin{abstract}
The partition of salts between two polar immiscible solvents results from the partition of the cations and anions. Because electroneutrality rules in both phases, the partition of cations is affected by that of anions, and vice versa. Thus, the partition of a salt is determined by the chemical potentials of cations and anions in both phases, and it is limited by the boundary condition of electroneutrality. Whereas the partition of neutral molecules does not produce a Galvani potential difference at the interface, the partition of salts does. Here, the equations to calculate this Galvani potential difference are derived for salts of the general composition $\mathrm{Cat}_{v_{\mathrm{Cat}}}^{\left(z_{\mathrm{Cat}}\right)+} \mathrm{An}_{v_{\mathrm{An}}}^{\left(z_{\mathrm{An}}\right)-}$ and for uni-univalent salts $\mathrm{Cat}^{+} \mathrm{An}^{-}$. The activity of a specific ion in a particular phase can thus be purposefully tuned by the choice of a suitable counterion. Finally, the distribution of a salt between its solid phase and its saturated solution is also presented, together with a discussion of the Galvani potential difference across the interface of the two phases.
\end{abstract}

\section{Graphical abstract}

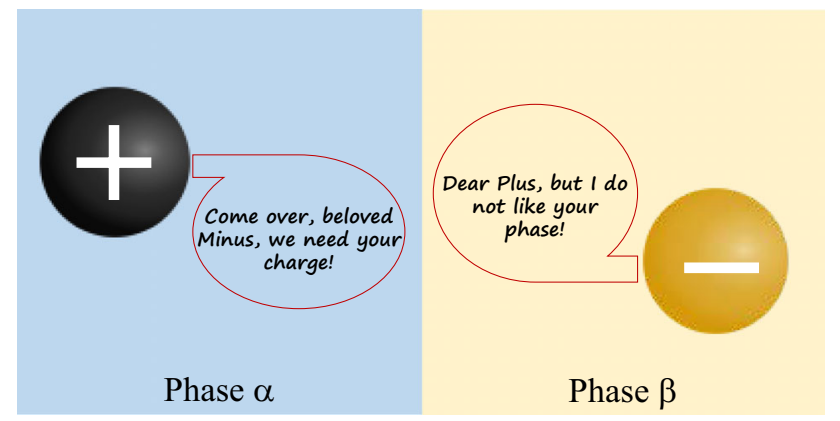

Keywords Partition · Partition constant · Ion · Salt · Electrolyte · Galvani potential difference · Ion adsorption · Fajans · Precipitation - Titration

\section{List of symbols}

Fritz Scholz and Heike Kahlert equally contributed as authors.

Fritz Scholz

fscholz@uni-greifswald.de

$\triangle$ Heike Kahlert

hkahlert@uni-greifswald.de

1 Institut für Biochemie, Universität Greifswald, FelixHausdorff-Str. 4, 17489 Greifswald, Germany

\begin{tabular}{|c|c|}
\hline \multicolumn{2}{|c|}{ Latin symbols } \\
\hline$a$ & Activity \\
\hline A & Neutral compound A \\
\hline $\operatorname{An}^{\left(z_{\mathrm{An}}\right)-}$ & Anion An with $z$ negative charges \\
\hline $\mathrm{B}, \mathrm{C}, \ldots$ & Compounds B, C, etc. \\
\hline$c$ & Molar concentration \\
\hline$c^{*}$ & Standard concentration $\left(1 \mathrm{~mol} \mathrm{~L}^{-1}\right)$ \\
\hline $\mathrm{Cat}^{\left(z_{\text {Cat }}\right)+}$ & Cation Cat with $z$ positive charges \\
\hline DCM & Dichloromethane \\
\hline
\end{tabular}




\begin{tabular}{|c|c|}
\hline $\mathrm{e}^{-}$ & Electron \\
\hline $\mathrm{E}$ & Electrolyte \\
\hline$E$ & Electric potential \\
\hline & Activity coefficient \\
\hline$F$ & $\begin{array}{l}\text { Faraday constant }(9.64853383(83) \times \\
\left.10^{4} \mathrm{C} \mathrm{mol}^{-1}\right)\end{array}$ \\
\hline$g$ & Free energy (Gibbs energy) \\
\hline$G$ & Molar free energy (molar Gibbs energy) \\
\hline$\Delta_{\alpha \rightarrow \beta} G_{\mathrm{A}}^{\ominus}$ & $\begin{array}{l}\text { Standard Gibbs energy of transfer of A from } \\
\text { phase } \alpha \text { to phase } \beta\end{array}$ \\
\hline$K_{\mathrm{IP}}$ & $\begin{array}{l}\text { Formation constant of ion pairs (association } \\
\text { constant) }\end{array}$ \\
\hline$K_{\mathrm{p}(\mathrm{A}), T, p}$ & Partition constant of species A \\
\hline$K_{\mathrm{sp}}$ & Solubility product \\
\hline i & Chemical species i \\
\hline IP & Ion pair \\
\hline $\ln$ & $\begin{array}{l}\text { Natural logarithm (logarithm to the base e, with } \\
\text { e being the Euler constant) }\end{array}$ \\
\hline $\log$ & Decadic logarithm (logarithm to the base 10) \\
\hline M & Metal phase \\
\hline$n$ & $\begin{array}{l}\text { Amount of substance (unit: mol) of atoms, } \\
\text { molecules, ions or electrons }\end{array}$ \\
\hline $\mathrm{nb}$ & Nitrobenzene \\
\hline Ox & Oxidized form of a redox pair \\
\hline $\mathrm{p}$ & Partition \\
\hline$p$ & Pressure \\
\hline $\mathrm{pic}^{-}$ & Picrate (2,4,6-trinitrophenolate) \\
\hline$R$ & $\begin{array}{l}\text { Universal gas constant } \\
\left(8.31446261815324 \mathrm{~J} \mathrm{~K}^{-1} \mathrm{~mol}^{-1}\right)\end{array}$ \\
\hline Red & Reduced form of a redox pair \\
\hline s & Indicates a solid phase (here a salt phase) \\
\hline sol & Indicates a solution phase \\
\hline$T$ & Absolute temperature \\
\hline $\mathrm{TBA}^{+}$ & Tetrabutylammonium ion \\
\hline $\mathrm{TEA}^{+}$ & Tetraethylammonium ion \\
\hline TMA $^{+}$ & Tetramethylammonium ion \\
\hline $\mathrm{TPA}^{+}$ & Tetraphenylarsonium ion \\
\hline $\mathrm{TPB}^{-}$ & Tetraphenylborate ion \\
\hline $\mathrm{w}$ & Water \\
\hline$z$ & $\begin{array}{l}\text { Charge of an ion, number of exchanged } \\
\text { electrons }\end{array}$ \\
\hline
\end{tabular}

\section{Greek symbols}

$\beta$

$\mu$

$\bar{\mu}$

$v$

$\phi$
$\Delta_{\alpha, \beta} \phi$

$\Delta_{\mathrm{s}, \mathrm{sol}} \phi_{\mathrm{c}, \mathrm{i}}^{\ominus}$

Difference of inner electric potentials of the phases phase $\alpha$ and $\beta$, i.e. the Galvani potential difference between these two phases. It is defined as $\Delta_{\alpha, \beta} \phi=\phi_{\beta}-\phi_{\alpha}$

Formal potential of ion transfer

\section{Other symbols}

Plimsoll symbol, as superscript indicating standard quantities

\section{Introduction}

The partition of neutral compounds between immiscible solvents is very well covered in textbooks of general, physical and analytical chemistry; however, the partition of salts can be found only in special monographs, where it is often presented in a form which is not easily understandable for students. Here, we provide an introductory text discussing salt partition on the basis of the thermodynamics as taught in Bachelor courses.

The partition of salts is of high importance in many fields of science: ion transfer (e.g. of drugs) through membranes, ion transfer catalysis in organic synthesis, and extraction of metal ions in analytical chemistry are just the most common examples.

When the partition of compounds between liquid phases is treated, usually the phrase 'partition between two immiscible liquid phases' is used. However, completely immiscible liquids do not exist. That phrase just points to those systems where the mutual miscibility is so small that the phases can be considered as pure phases, at least for a simplified treatment.

\section{Partition of neutral compounds between two immiscible solution phases}

The Nernst distribution law describes the partition of a neutral compound A between two immiscible liquid phases $\alpha$ and $\beta$

$\mathrm{A}_{\alpha} \rightleftarrows \mathrm{A}_{\beta}$.

(Equilibrium I)

An example is the distribution of iodine between water and tetrachloromethane. Walter Nernst published the respective equation in 1891 [1]. In modern terms, it states that the ratio of activities [2] of the compound in the two phases is constant at constant temperature $(T)$ and pressure $(p)$ :

$K_{\mathrm{p}(\mathrm{A}), T, p}=a_{\mathrm{A}, \beta} / a_{\mathrm{A}, \alpha}$

$K_{\mathrm{p}(\mathrm{A}), T, p}$ is called the partition constant of $\mathrm{A}$, and the upright $\mathrm{p}$ in the subscript stands for partition. In 
equilibrium, the chemical potentials $\mu_{\mathrm{A}, \alpha}$ and $\mu_{\mathrm{A}, \beta}$ of the distributed compound $\mathrm{A}$ must be the same in both phases:

$\mu_{\mathrm{A}, \alpha}=\mu_{\mathrm{A}, \beta}$.

Remember, the chemical potential is the partial derivative of the Gibbs energy over the amount (unit: mol) of substance (atoms, molecules or ions) (here of A), at constant temperature, pressure and constant amounts (unit: mol) of all other compounds (e.g. B, C, etc.):

$\mu_{\mathrm{A}}=\left(\frac{\partial g}{\partial n_{\mathrm{A}}}\right)_{T, p, n_{\mathrm{B}}, n_{\mathrm{C}}, \ldots}$

This means that the chemical potential is a measure of the ability to produce or consume work. Since a system does not produce or consume work when it is in equilibrium, the chemical potentials of $\mathrm{A}$ in the phases $\alpha$ and $\beta$ must be equal at equilibrium, as otherwise a flux of $\mathrm{A}$ from one phase to the other would occur. Since the chemical potential of $\mathrm{A}$ can be split into a standard term $\mu_{\mathrm{A}}^{\ominus}$ (the chemical standard potential) and an activity-dependent term:

$\mu_{\mathrm{A}}=\mu_{\mathrm{A}}^{\ominus}+R T \ln a_{\mathrm{A}}$

it follows from the condition (2) that

$\mu_{\mathrm{A}, \alpha}^{\ominus}+R T \ln a_{\mathrm{A}, \alpha}=\mu_{\mathrm{A}, \beta}^{\ominus}+R T \ln a_{\mathrm{A}, \beta}$,

$\mu_{\mathrm{A}, \alpha}^{\ominus}-\mu_{\mathrm{A}, \beta}^{\ominus}=R T \ln a_{\mathrm{A}, \beta}-R T \ln a_{\mathrm{A}, \alpha}$.

The difference of chemical standard potentials is a constant:

$\mu_{\mathrm{A}, \alpha}^{\ominus}-\mu_{\mathrm{A}, \beta}^{\ominus}=R T \ln \frac{a_{\mathrm{A}, \beta}}{a_{\mathrm{A}, \alpha}}=2.303 R T \log \frac{a_{\mathrm{A}, \beta}}{a_{\mathrm{A}, \alpha}}$.

Since the partition constant has been defined as $K_{\mathrm{p}(\mathrm{A}), T, p}=a_{\mathrm{A}, \beta} / a_{\mathrm{A}, \alpha}(1)$, the following equation results from (7) and (1):

$K_{\mathrm{p}(\mathrm{A}), T, p}=\frac{a_{\mathrm{A}, \beta}}{a_{\mathrm{A}, \alpha}}=\mathrm{e}^{\frac{\mu_{\mathrm{A}, \alpha}^{\ominus}-\mu_{\mathrm{A}, \beta}^{\ominus}}{R T}}=10^{\mu_{\mathrm{A}, \alpha}^{\ominus}-\mu_{\mathrm{A}, \beta}^{\ominus}}{ }^{\ominus 2.03 R T}$.

Equation (8) nicely shows that $K_{\mathrm{p}(\mathrm{A}), T, p}$ is larger than 1 when $\mu_{\mathrm{A}, \alpha}^{\ominus}>\mu_{\mathrm{A}, \beta}^{\ominus}$, and smaller than 1 for $\mu_{\mathrm{A}, \alpha}^{\ominus}<\mu_{\mathrm{A}, \beta}^{\ominus}$. Equation (8) can also be written using the standard Gibbs energy of transfer $\Delta_{\alpha \rightarrow \beta} G_{\mathrm{A}}^{\ominus}$ of A from phase $\alpha$ to phase $\beta$, defined as

$\Delta_{\alpha \rightarrow \beta} G_{\mathrm{A}}^{\ominus}=\mu_{\mathrm{A}, \beta}^{\ominus}-\mu_{\mathrm{A}, \alpha}^{\ominus}$.

Because a Gibbs energy difference always refers to a certain direction of the reaction, the arrow in the subscript indicates here the transfer from phase $\alpha$ to $\beta$. With Eq. (9) it is possible to write Eq. (8) as follows:
$K_{\mathrm{p}(\mathrm{A}), T, p}=\frac{a_{\mathrm{A}, \beta}}{a_{\mathrm{A}, \alpha}}=10^{-\frac{\Delta_{\alpha \rightarrow \beta} G_{\mathrm{i}}^{\ominus}}{2.303 R T}}$

\section{Partition of a salt $\mathrm{Cat}_{v_{\text {Cat }}}^{\left(z_{\text {Cat }}\right)+} \operatorname{An}_{v_{\text {An }}}^{\left(z_{\text {An }}\right)-}$ between two immiscible solution phases}

For a very simple reason, the partition of a salt between immiscible solvents is more complex than that of neutral compounds: the two constituents of a salt, i.e. cations and anions, are on one side free in solution, but on the other side, their transfer to the other phase is restricted by the condition of electroneutrality in both bulk phases. The electroneutrality is the boundary condition for the partition. Only in the interfacial region (double layer region), where the two phases meet, is the condition of electroneutrality violated. This causes the occurrence of an interfacial potential difference called Galvani potential difference. A salt Cat $v_{v_{\text {Cat }}}^{\left(z_{\text {Cat }}\right)+} \mathrm{An}_{v_{\mathrm{An}}}^{\left(z_{\mathrm{An}}\right)-}$ partitions between two polar immiscible solvent phases $\alpha$ and $\beta$ according to

$v_{\mathrm{Cat}, \alpha} \mathrm{Cat}_{\alpha}^{\left(z_{\mathrm{Cat}}\right)+}+v_{\mathrm{An}, \alpha} \mathrm{An}_{\alpha}^{\left(z_{\mathrm{An}}\right)-} \rightleftarrows v_{\mathrm{Cat}, \beta} \mathrm{Cat}_{\beta}^{\left(z_{\mathrm{Cat}}\right)+}+v_{\mathrm{An}, \beta} \mathrm{An}_{\beta}^{\left(z_{\mathrm{An}}\right)-}$.

(Equilibrium II)

Since the stoichiometry of the salt is the same in both phases, i.e. $v_{\mathrm{Cat}, \alpha}=v_{\mathrm{Cat}, \beta}=v_{\mathrm{Cat}}$ and $v_{\mathrm{An}, \alpha}=v_{\mathrm{An}, \beta}=v_{\mathrm{An}}$, one can write

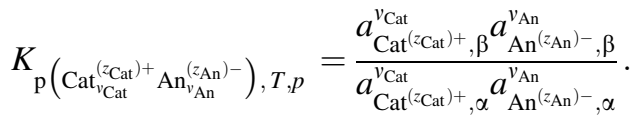

Equilibrium II indicates that the salt is assumed to be completely dissociated in both phases, i.e. no ion pairs exist in the two phases. Ion pairs, e.g. $\left[\mathrm{Cat}^{+} \mathrm{An}^{-}\right]_{\text {ionpair }}$ of a uni-univalent salt, form when the electrostatic attraction between the opposite charged ions is not overcome by the free energy of solvation of the single ions (see the example of $\left[\mathrm{TBA}^{+} \mathrm{pic}^{-}\right]$at the end of this paper). This happens especially in solvents which have a low dielectric constant, i.e. which are rather nonpolar. Neglecting ion pairs is certainly a simplification, as ion pairs are in principle ubiquitous in electrolyte solutions. However, if the liquid phases have a high polarity, their formation may be negligible. When one liquid phase is water (a polar solvent), and the other solvent is also polar, like nitrobenzene, ion pairing can be neglected in both phases. Further, the partition could be affected by complex formation or any other chemical equilibria involving the partitioning ions. All these side reactions are excluded in the present treatment.

Figure 1 shows a scheme of the Equilibrium II as the result of the partition equilibria of the cations and anions. 
Although the two bulk phases maintain electroneutrality by having equal numbers of negative and positive charges, at the interface of the two phases a Galvani potential difference builds up if the two partition constants

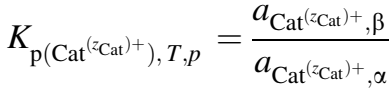

and

$K_{\mathrm{p}\left(\mathrm{An}^{\left(z_{\mathrm{An}}\right)-}\right), T, p}=\frac{a_{\mathrm{An}^{\left(z_{\mathrm{An}}\right)-}, \beta}}{a_{\mathrm{An}^{\left(z_{\mathrm{An}}\right)-}, \alpha}}$

do not have identical values. When these constants differ from each other, which is the case for almost all salts, a minute charge separation occurs across the interface, resulting in the Galvani potential difference:

$\Delta_{\alpha, \beta} \phi=\phi_{\beta}-\phi_{\alpha}$

where $\phi_{\alpha}$ and $\phi_{\beta}$ are the inner electric potentials of the two phases. The determination of the two equilibrium constants would need to know the activity of each single kind of ion, i.e. of the cations and the anions. The situation at the interface shown in Fig. 1 is to some extent similar to that at the interface of an electrode, where an oxidation and reduction can proceed: quantification of a redox equilibrium at an electrode needs to define the zero point of the Galvani potential difference. For the basics of interfacial and especially electrochemical thermodynamics, we suggest the papers by Láng [3] and Inzelt [4]. In the case of redox equilibria the convention is that the Galvani potential difference at the platinumlsolution interface of the standard hydrogen electrode is zero. In the case of ion partition equilibria, the commonly accepted convention (there are also other conventions) is that tetraphenylarsonium $\left(\mathrm{TPA}^{+}\right)$ cations and tetraphenylborate ( $\mathrm{TPB}^{-}$) anions have identical partition constants [5], because they are equally bulky ions and both are single charged:

$K_{\mathrm{p}\left(\mathrm{TPA}^{+}\right), T, p}=K_{\mathrm{p}\left(\mathrm{TPB}^{-}\right), T, p}$.

Partition of this salt produces a zero cell voltage (see the end of this text) of the electrochemical cell:

$\mathrm{M}_{1} \mid \mathrm{E}_{1} \vdots$ salt bridge $1 \vdots$ phase $\alpha \mid$ phase $\beta \vdots$ salt bridge $2 \vdots$ $\mathrm{E}_{2} \mid \mathrm{M}_{2}$

$M_{1}$ is the metal phase of reference electrode $1, E_{1}$ is the electrolyte of reference electrode $1, \mathrm{M}_{2}$ is the metal phase of reference electrode $2, \mathrm{E}_{2}$ is the electrolyte of reference electrode 2, the vertical bar I symbolises a phase boundary, and the dashed vertical bar stands for a junction between miscible solutions. When the two reference electrodes are identical, the measured cell voltage is the Galvani potential difference across the interface of $\alpha$ with $\beta$ defined as $\Delta_{\alpha, \beta} \phi=\phi_{\beta}-\phi_{\alpha}$, plus the diffusion potentials at the junctions of the different solutions. The latter can be

$$
\begin{aligned}
& \text { Phase } \alpha \\
& \mathrm{Cat}_{\alpha}^{\left(z_{\mathrm{Cat}}\right)+} \rightleftarrows \mathrm{Cat}_{\beta}^{\left(z_{\mathrm{Cat}}\right)+} \\
& K_{\mathrm{p}\left(\mathrm{Cat}^{\left.(z \mathrm{Cat})^{+}\right), T, p}\right.}=\frac{a_{\mathrm{Cat}^{(z \mathrm{Cat})^{+}, \beta}}}{a_{\mathrm{Cat}^{\left({ }^{2} \mathrm{Cat}\right)^{+}, \alpha}}} \\
& \phi_{\alpha} \\
& \mathrm{An}_{\alpha}^{\left(z_{\mathrm{An}}\right)-} \rightleftarrows \mathrm{An}_{\beta}^{\left(z_{\mathrm{An}}\right)-} \\
& \begin{array}{c}
K_{\mathrm{p}\left(\mathrm{An}^{\left(z_{\mathrm{An}}\right)-}\right), T, p}=\frac{a_{\mathrm{An}^{\left(z_{\mathrm{An}}\right)-}, \beta}}{a_{\mathrm{An}^{\left(z_{\mathrm{An}}\right)-}, \alpha}} \\
\Delta_{\alpha, \beta} \phi=\phi_{\beta}-\phi_{\alpha}
\end{array} \\
& \begin{array}{c}
K_{\mathrm{p}\left(\mathrm{An}^{\left(z_{\mathrm{An}}\right)-}\right), T, p}=\frac{a_{\mathrm{An}^{\left(z_{\mathrm{An}}\right)-}, \beta}}{a_{\mathrm{An}^{\left(z_{\mathrm{An}}\right)}, \alpha}} \\
\Delta_{\alpha, \beta} \phi=\phi_{\beta}-\phi_{\alpha}
\end{array}
\end{aligned}
$$

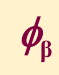

Fig. 1 The partition of the ions of a salt having the formula $\mathrm{Cat}_{v_{\mathrm{Cat}}}^{\left(z_{\mathrm{Cat}}\right)+} \mathrm{An}_{v_{\mathrm{An}}}^{\left(z_{\mathrm{An}}\right)-}$ between two phases is the result of the partition equilibria of anions and cations

minimised, so that the Galvani potential difference between the phases $\alpha$ and $\beta$ is the major contribution. The calculation of the partition constant $K_{\mathrm{p}}\left(\mathrm{Cat}_{{ }^{\mathrm{C} C a t}}^{\left({ }_{\mathrm{Z}} \mathrm{Cat}\right)+} \mathrm{An}_{v_{\mathrm{An}}}^{\left(z_{\mathrm{An}}\right)-}\right), T, p$ of the salt can be attempted by calculation of

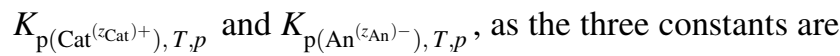
related as follows:

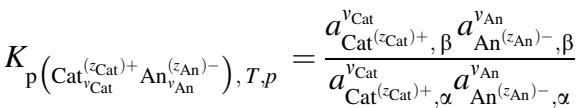

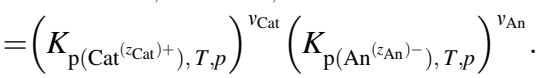

\section{Ion partition between two immiscible solution phases}

Since ions are charged particles, the transfer from one phase to another phase involves electric work, when the two phases have different inner electrical potentials. This work, expressed as a molar quantity, is the charge of the ion $z_{\mathrm{i}}$ multiplied by the charge of one mole unit charges (the Faraday constant), multiplied by the difference of inner electric potentials $\phi_{\alpha}$ and $\phi_{\beta}$ between the two phases, i.e. $z_{\mathrm{i}} F\left(\phi_{\beta}-\phi_{\alpha}\right)$. The sum of chemical and electrical work for the transfer of ions from infinity (outside the respective phases) to the inner of the respective phases is the so-called electrochemical potential, here $\bar{\mu}_{\mathrm{i}, \alpha}$ and $\bar{\mu}_{\mathrm{i}, \beta}$ :

$\bar{\mu}_{\mathrm{i}, \alpha}=\mu_{\mathrm{i}, \alpha}+z_{\mathrm{i}} F \phi_{\alpha}$,

$\bar{\mu}_{\mathrm{i}, \beta}=\mu_{\mathrm{i}, \beta}+z_{\mathrm{i}} F \phi_{\beta}$. 
The equilibrium condition for ions is the equality of electrochemical potentials, i.e. $v_{\mathrm{i}, \alpha} \bar{\mu}_{\mathrm{i}, \alpha}=v_{\mathrm{i}, \beta} \bar{\mu}_{\mathrm{i}, \beta}$, since the electric work cannot be neglected:

$v_{\mathrm{i}, \alpha} \mu_{\mathrm{i}, \alpha}+v_{\mathrm{i}, \alpha} z_{\mathrm{i}} F \phi_{\alpha}=v_{\mathrm{i}, \beta} \mu_{\mathrm{i}, \beta}+v_{\mathrm{i}, \beta} z_{\mathrm{i}} F \phi_{\beta}$.

When the partition is not affected by any chemical reactions, the stoichiometry of the salt remains unaffected in both phases, and for the cations and anions the relation $v_{\mathrm{i}, \alpha}=v_{\mathrm{i}, \beta}$, must hold true:

$\mu_{\mathrm{i}, \alpha}+z_{\mathrm{i}} F \phi_{\alpha}=\mu_{\mathrm{i}, \beta}+z_{\mathrm{i}} F \phi_{\beta}$.

This allows the calculation of the Galvani potential difference caused by partition of the ions, either cations or anions:

$z_{\mathrm{i}} F \phi_{\beta}-z_{\mathrm{i}} F \phi_{\alpha}=\mu_{\mathrm{i}, \alpha}-\mu_{\mathrm{i}, \beta}$

$\Delta_{\alpha, \beta} \phi_{\mathrm{i}}=\phi_{\beta}-\phi_{\alpha}=\frac{\mu_{\mathrm{i}, \alpha}-\mu_{\mathrm{i}, \beta}}{z_{\mathrm{i}} F}$.

Since the chemical potential of a species i is $\mu_{\mathrm{i}}=$ $\mu_{\mathrm{i}}^{\ominus}+R T \ln a_{\mathrm{i}}$ (Eq. 4), one can write Eq. (22) as follows:

$\Delta_{\alpha, \beta} \phi_{\mathrm{i}}=\frac{1}{z_{\mathrm{i}} F}\left(\mu_{\mathrm{i}, \alpha}^{\ominus}+R T \ln a_{\mathrm{i}, \alpha}-\mu_{\mathrm{i}, \beta}^{\ominus}-R T \ln a_{\mathrm{i}, \beta}\right)$,

$\Delta_{\alpha, \beta} \phi_{\mathrm{i}}=\frac{\mu_{\mathrm{i}, \alpha}^{\ominus}-\mu_{\mathrm{i}, \beta}^{\ominus}}{z_{\mathrm{i}} F}+\frac{R T}{z_{\mathrm{i}} F} \ln \frac{a_{\mathrm{i}, \alpha}}{a_{\mathrm{i}, \beta}}$.

The term $\frac{\mu_{\mathrm{i}, \alpha}^{\ominus}-\mu_{\mathrm{i}, \beta}^{\ominus}}{z_{\mathrm{i}} \mathrm{F}}$ defines the standard potential of ion transfer (cf. Eq. 9):

$\Delta_{\alpha, \beta} \phi_{\mathrm{i}}^{\ominus}=\frac{\mu_{\mathrm{i}, \alpha}^{\ominus}-\mu_{\mathrm{i}, \beta}^{\ominus}}{z_{\mathrm{i}} F}=-\frac{\Delta_{\alpha \rightarrow \beta} G_{\mathrm{i}}^{\ominus}}{z_{\mathrm{i}} F}$

since $\Delta_{\alpha \rightarrow \beta} G_{\mathrm{i}}^{\ominus}=\mu_{\mathrm{i}, \beta}^{\ominus}-\mu_{\mathrm{i}, \alpha}^{\ominus}$, which is the standard Gibbs energy of transfer of the ions from phase $\alpha$ to $\beta$, Eq. (24) can be written as follows:

$$
\begin{aligned}
\Delta_{\alpha, \beta} \phi_{\mathrm{i}} & =\Delta_{\alpha, \beta} \phi_{\mathrm{i}}^{\ominus}+\frac{R T}{z_{\mathrm{i}} F} \ln \frac{a_{\mathrm{i}, \alpha}}{a_{\mathrm{i}, \beta}} \\
& =-\frac{\Delta_{\alpha \rightarrow \beta} G_{\mathrm{i}}^{\ominus}}{z_{\mathrm{i}} F}+\frac{R T}{z_{\mathrm{i}} F} \ln \frac{a_{\mathrm{i}, \alpha}}{a_{\mathrm{i}, \beta}} \\
& =-\frac{\Delta_{\alpha \rightarrow \beta} G_{\mathrm{i}}^{\ominus}}{z_{\mathrm{i}} F}+\frac{R T}{z_{\mathrm{i}} F} \ln \frac{1}{K_{\mathrm{p}(\mathrm{i}), \mathrm{T}, \mathrm{p}}} .
\end{aligned}
$$

The $K_{\mathrm{p}(\mathrm{i}), T, p}$ used here is defined in Eq. (1) as $\frac{a_{\mathrm{i}, \beta}}{a_{\mathrm{i}, \alpha}}$, but one needs to remember that this is the chemical equilibrium constant for which equality of the inner electric potentials of the two phases is a prerequisite. Hence,

$\ln K_{\mathrm{p}(\mathrm{i}), T, p}=\ln \frac{a_{\mathrm{i}, \beta}}{a_{\mathrm{i}, \alpha}}=-\frac{\Delta_{\alpha \rightarrow \beta} G_{\mathrm{i}}^{\ominus}}{R T}$,
Table 1 Standard Gibbs energies of transfer of ions from water to nitrobenzene $\Delta_{\mathrm{w} \rightarrow \mathrm{nb}} G_{\mathrm{i}}^{\ominus}$, and the standard Galvani potential differences $\Delta_{\mathrm{w}, \mathrm{nb}} \phi_{\mathrm{i}}^{\ominus}$ (corresponding to $\Delta_{\alpha, \beta} \phi_{\mathrm{i}}^{\ominus}$ in this text, i.e. $\left.\Delta_{\mathrm{w}, \mathrm{nb}} \phi_{\mathrm{i}}^{\ominus}=\phi_{\mathrm{i}, \mathrm{nb}}^{\ominus}-\phi_{\mathrm{i}, \mathrm{w}}^{\ominus}\right)$

\begin{tabular}{lccc}
\hline Ion & $\Delta_{\mathrm{w} \rightarrow \mathrm{nb}} G_{\mathrm{i}}^{\ominus}\left(\mathrm{kJ} \mathrm{mol}^{-1)}\right.$ & $\Delta_{\mathrm{w}, \mathrm{nb}} \phi_{\mathrm{i}}^{\ominus}(\mathrm{mV})$ & References \\
\hline $\mathrm{K}^{+}$ & 22.65 & -235 & {$[13]$} \\
$\mathrm{Rb}^{+}$ & 19.80 & -205 & {$[13]$} \\
$\mathrm{Tl}^{+}$ & 19.30 & -200 & {$[13]$} \\
$\mathrm{Cs}^{+}$ & 17.80 & -184 & {$[13]$} \\
$\mathrm{TMA}^{+}$ & 9.60 & -99 & {$[13]$} \\
$\mathrm{TEA}^{+}$ & -0.50 & 5 & {$[13]$} \\
$\mathrm{TBA}^{+}$ & -8.20 & 85 & {$[13]$} \\
$\mathrm{TPB}^{-}$ & -35.90 & -372 & {$[11]$} \\
$\mathrm{Picrate}^{+}$ & -3.00 & -31 & {$[13]$} \\
$\mathrm{ClO}_{4}^{-}$ & 8.00 & 83 & {$[11]$} \\
$\mathrm{I}^{-}$ & 18.80 & 195 & {$[11]$} \\
$\mathrm{ClO}_{3}^{-}$ & 25.40 & 263 & {$[13]$} \\
$\mathrm{Cl}^{-}$ & 31.40 & 325 & {$[11]$} \\
\hline
\end{tabular}

$K_{\mathrm{p}(\mathrm{i}), T, p}=\mathrm{e}^{-\frac{\Delta_{\alpha \rightarrow \beta} \mathrm{G}_{\mathrm{i}}}{R T}}=10^{-\frac{\Delta_{\alpha \rightarrow \beta} \mathrm{G}_{\mathrm{i}}^{\ominus}}{2.303 R T}}$

(For comparison, see also Eqs. (8-10)). Alternatively, one can give the relations

$\ln K_{\mathrm{p}(\mathrm{i}), T, p}=\frac{z_{\mathrm{i}} F}{R T} \Delta_{\alpha, \beta} \phi_{\mathrm{i}}^{\ominus}$,

$K_{\mathrm{p}(\mathrm{i}), T, p}=\mathrm{e}^{\frac{z_{i} F}{R T} \Delta_{\alpha, \beta} \phi_{\mathrm{i}}^{\ominus}}=10^{\frac{z_{i} F}{2.303 R T} \Delta_{\alpha, \beta} \phi_{\mathrm{i}}^{\ominus}}$.

Since $\ln \frac{1}{K_{\mathrm{p}(\mathrm{i}) T, p}}=\ln \frac{a_{\mathrm{i}, \alpha}}{a_{i, \beta}}=\frac{\Delta_{\alpha-\beta} G_{i}^{\ominus}}{R T}, \quad$ it follows with Eq. (26) that $\Delta_{\alpha, \beta} \phi_{\mathrm{i}}$ is zero: $\Delta_{\alpha, \beta} \phi_{\mathrm{i}}=-\frac{\Delta_{\alpha \rightarrow \beta} G_{\mathrm{i}}^{\ominus}}{z_{\mathrm{i}} F}+\frac{R T}{z_{\mathrm{i}} F}$ $\ln \frac{1}{K_{\mathrm{p}(\mathrm{i}), T, p}}=-\frac{\Delta_{\alpha \rightarrow \beta} G_{\mathrm{i}}^{\ominus}}{z_{\mathrm{i}} F}+\frac{\Delta_{\alpha \rightarrow \beta} G_{\mathrm{i}}^{\ominus}}{z_{\mathrm{i}} F}=0$, which was the condition to define the chemical equilibrium constant.

In Table 1 standard Gibbs energies of ion transfer and the corresponding standard Galvani potential differences are given for selected ions.

The hydrophilicity of cations increases with increasing $\Delta_{\mathrm{w} \rightarrow \mathrm{nb}} G_{\mathrm{i}}^{\ominus}$ and with decreasing $\Delta_{\alpha, \beta} \phi_{\mathrm{i}}^{\ominus}$. The hydrophilicity of anions also increases with increasing $\Delta_{\mathrm{w} \rightarrow \mathrm{nb}} G_{\mathrm{i}}^{\ominus}$, but with increasing $\Delta_{\alpha, \beta} \phi_{i}^{\ominus}$. The latter is a result of the negative charge of the anions. In the case of the transfer of ions from water to nitrobenzene, increasing values of $\Delta_{\mathrm{w} \rightarrow \mathrm{nb}} G_{\mathrm{i}}^{\ominus}$ imply that fewer ions are transferred to nitrobenzene. 


\section{Partition of $\mathrm{Cat}_{v_{\mathrm{Cat}}}^{\left(z_{\mathrm{Cat}}\right)+} \mathrm{An}_{v_{\mathrm{An}}}^{\left(z_{\mathrm{An}}\right)-}$ between two immiscible solution phases}

Now we need to consider the interplay of cation and anion partition: The chemical interaction of the ions with the two solvents is always different for the cations and anions (with the exception of very few salts, like the $\mathrm{TPA}^{+} \mathrm{TPB}^{-}$mentioned above). Therefore, the partition of cations is affected by that of anions, and vice versa. The difference of inner electric potentials $\Delta_{\alpha, \beta} \phi_{\mathrm{i}}$ is not zero, as in the theoretical case of single ion partition discussed in connection with Eq. (27). The Galvani potential differences caused by the cations $\Delta_{\alpha, \beta} \phi_{\mathrm{Cat}{ }^{\left({ }^{2} \mathrm{Cat}\right)}+}$ and anions $\Delta_{\alpha, \beta} \phi_{\mathrm{An}\left({ }^{\left(\mathrm{z}_{\mathrm{An}}\right)-}\right.}$ must be equal to the overall Galvani potential difference

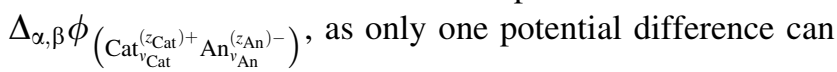
exist at one interface.

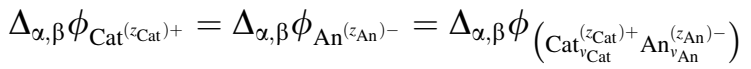

Now, Eq. (26) can be formulated for the cations

$$
\begin{aligned}
& \Delta_{\alpha, \beta} \phi_{\mathrm{Cat}}{ }^{\left(z_{\mathrm{Cat}}\right)+}=\Delta_{\alpha, \beta} \phi\left(\mathrm{Cat}_{v_{\mathrm{Cat}}}^{\left(z_{\mathrm{Cat}}\right)+} \mathrm{An}_{v_{\mathrm{An}}}^{\left(z_{\mathrm{An}}\right)-}\right) \\
& =\Delta_{\alpha, \beta} \phi_{\mathrm{Cat}{ }^{\left(z_{\mathrm{Cat}}\right)+}}^{\ominus}+\frac{R T}{z_{\mathrm{Cat}} F} \ln \frac{a_{\mathrm{Cat}}{ }^{\left(z_{\mathrm{Cat}}\right)+}, \alpha}{a_{\mathrm{Cat}{ }^{\left(z_{\mathrm{Cat}}\right)+}, \beta}} .
\end{aligned}
$$

For the anions Eq. (26) follows

$$
\begin{aligned}
& \Delta_{\alpha, \beta} \phi_{\mathrm{An}^{\left(z_{\mathrm{An}}\right)-}}=\Delta_{\alpha, \beta} \phi\left(\mathrm{Cat}_{{ }^{\mathrm{C}} \mathrm{Cat}}^{\left(z_{\mathrm{Cat}}\right)+}{ }_{\mathrm{An}_{v_{\mathrm{An}}}}^{\left(z_{\mathrm{An}}\right)-}\right) \\
& =\Delta_{\alpha, \beta} \phi_{\mathrm{An}^{\left(z_{\mathrm{An}}\right)-}}^{\ominus}+\frac{R T}{z_{\mathrm{An}} F} \ln \frac{a_{\mathrm{An}^{\left(z_{\mathrm{An}}\right)-}, \alpha}}{a_{\mathrm{An}^{\left(z_{\mathrm{An}}\right)-, \beta}}}
\end{aligned}
$$

or

$$
\begin{aligned}
\Delta_{\alpha, \beta} \phi_{\mathrm{An}^{\left(z_{\mathrm{An}}\right)-}} & =\Delta_{\alpha, \beta} \phi\left(\mathrm{Cat}_{v_{\mathrm{Cat}}}^{\left(z_{\mathrm{Cat}}\right)+} \operatorname{An}_{v_{\mathrm{An}}}^{\left(z_{\mathrm{An}}\right)-}\right) \\
& =\Delta_{\alpha, \beta} \phi_{\mathrm{An}^{\left(z_{\mathrm{An}}\right)-}}^{\ominus}-\frac{R T}{\left|z_{\mathrm{An}}\right| F} \ln \frac{a_{\mathrm{An}^{\left(z_{\mathrm{An}}\right)-}, \alpha}}{a_{\mathrm{An}{ }^{\left(z_{\mathrm{An}}\right)-}, \beta}} .
\end{aligned}
$$

To solve the equations for $\Delta_{\alpha, \beta} \phi\left(\mathrm{Cat}_{{ }^{\mathrm{Cat}}}^{\left({ }_{\mathrm{C} a t}\right)+} \mathrm{An}_{v_{\mathrm{An}}}^{\left(z_{\mathrm{An}}\right)-}\right)$, Eq. (32) has to be multiplied by $z_{\text {Cat }}$, and Eq. (34) by $\left|z_{\text {An }}\right|$ :

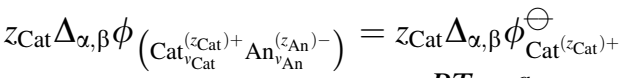

$$
\begin{aligned}
& +\frac{R T}{F} \ln \frac{a_{\mathrm{Cat}}{ }^{\left({ }^{2} \mathrm{Cat}\right)+}, \alpha}{a_{\mathrm{Cat}}{ }^{\left({ }^{\mathrm{Cat}}\right)+}, \beta} \text {. }
\end{aligned}
$$

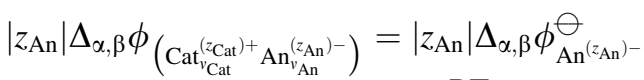

$$
\begin{aligned}
& -\frac{R T}{F} \ln \frac{a_{\mathrm{An}^{\left(z_{\mathrm{An}}\right)-}, \alpha}}{a_{\mathrm{An}^{\left(z_{\mathrm{An}}\right)-, \beta}} .}
\end{aligned}
$$

Now, Eqs. (35) and (36) can be summed up:

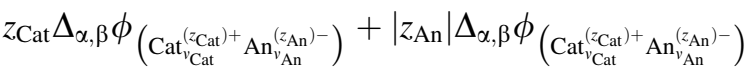

$$
\begin{aligned}
& =z_{\mathrm{Cat}} \Delta_{\alpha, \beta} \phi_{\mathrm{Cat}}^{\ominus}{ }^{\left(z_{\mathrm{Cat}}\right)+}+\left|z_{\mathrm{An}}\right| \Delta_{\alpha, \beta} \phi_{\mathrm{An}}^{\ominus}{ }^{\left(z_{\mathrm{An}}\right)-} \\
& +\frac{R T}{F} \ln \frac{a_{\left.\mathrm{Cat}^{\left({ }^{z} \mathrm{Cat}\right.}\right)^{+}, \alpha}}{a_{\left.\mathrm{Cat}^{\left({ }^{\mathrm{Cat}} \mathrm{Cat}\right.}\right)+, \beta}}-\frac{R T}{F} \ln \frac{a_{\mathrm{An}^{\left(z_{\mathrm{An}}\right)-}, \alpha}}{a_{\mathrm{An}^{\left(z_{\mathrm{An}}\right)-, \beta}}},
\end{aligned}
$$

and hence

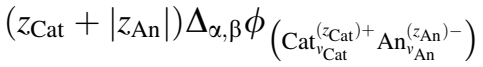

$$
\begin{aligned}
& =z_{\mathrm{Cat}} \Delta_{\alpha, \beta} \phi_{\mathrm{Cat}{ }^{\left({ }^{\mathrm{C} C a t}\right)}}^{\ominus}+\left|z_{\mathrm{An}}\right| \Delta_{\alpha, \beta} \phi_{\mathrm{An}^{\left(z_{\mathrm{An}}\right)-}}^{\ominus} \\
& +\frac{R T}{F} \ln \frac{a_{\mathrm{Cat}}{ }^{\left({ }^{\mathrm{Cat}}\right)+}{ }_{, \alpha} a_{\mathrm{An}^{\left(z_{\mathrm{An}}\right)-, \beta}}}{a_{\mathrm{Cat}{ }^{\left({ }^{\mathrm{Cat}}\right)+}, \beta} a_{\mathrm{An}^{\left(z_{\mathrm{An}}\right)-, \alpha}}}, \\
& \Delta_{\alpha, \beta} \phi\left(\mathrm{Cat}_{v_{\mathrm{Cat}}}^{\left(z_{\mathrm{Cat}}\right)+} \mathrm{An}_{v_{\mathrm{An}}}^{\left(z_{\mathrm{An}}\right)-}\right) \\
& =\frac{z_{\mathrm{Cat}} \Delta_{\alpha, \beta} \phi_{\mathrm{Cat}}^{\ominus}{ }^{\left(z_{\mathrm{Cat}}\right)+}+\left|z_{\mathrm{An}}\right| \Delta_{\alpha, \beta} \phi_{\mathrm{An}^{\left(z_{\mathrm{An}}\right)-}}^{\ominus}}{\left(z_{\mathrm{Cat}}+\left|z_{\mathrm{An}}\right|\right)} \\
& +\frac{R T}{\left(z_{\mathrm{Cat}}+\left|z_{\mathrm{An}}\right|\right) F} \ln \frac{a_{\mathrm{Cat}}{ }^{\left(z_{\mathrm{Cat}}\right)+, \alpha} a_{\mathrm{An}^{\left(z_{\mathrm{An}}\right)-, \beta}}}{a_{\mathrm{Cat}^{\left({ }^{2} \mathrm{Cat}\right.}{ }^{2}+, \beta} a_{\mathrm{An}^{\left(z_{\mathrm{An}}\right)-, \alpha}}} .
\end{aligned}
$$

Although Eq. (39) is reminiscent of the Nernst equation, the argument of the logarithm is not the partition

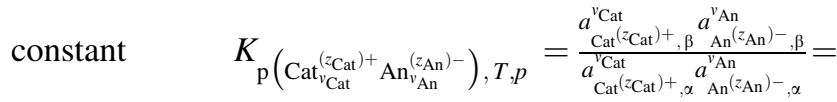
$\left(K_{\mathrm{p}\left(\mathrm{Cat}^{\left(z_{\mathrm{Cat}}\right)+}\right), T, p}\right)^{v_{\mathrm{Cat}}}\left(K_{\mathrm{p}\left(\mathrm{An}^{\left(z_{\mathrm{An}}\right)-}\right), T, p}\right)^{v_{\mathrm{An}}}$ (cf. Eq. 16), but the term $\frac{\left.a_{\mathrm{Cat}}{ }^{z} \mathrm{Cat}\right)+, \alpha{ }_{\mathrm{An}}\left(z_{\mathrm{An}}\right)-, \beta}{\left.a_{\mathrm{Cat}}{ }^{z} \mathrm{Cat}\right)+, \beta{ }_{\mathrm{An}}{ }^{\left(z_{\mathrm{An}}\right)-, \alpha}}$ in Eq. (39) is the ratio of the partition constants: $\frac{\left.K_{\mathrm{p}(\mathrm{An}}\left(z_{\mathrm{An}}\right)-\right), T, p}{\left.K_{\mathrm{p}(\mathrm{Cat}}\left(z_{\mathrm{Cat}}\right)+\right), T, p}$.

Taking into account that the activity $a_{\mathrm{i}}$ is defined as $a_{\mathrm{i}}=f_{\mathrm{i}} c_{\mathrm{i}} \frac{1}{c^{*}}$, where $f_{\mathrm{i}}$ is the activity coefficient of $\mathrm{i}, c_{\mathrm{i}}$ is the molar concentration of $\mathrm{i}$, and $c^{*}$ is the standard concentration ( $\left.1 \mathrm{~mol} \mathrm{~L}^{-1}\right)$, Eq. (39) assumes the form

$$
\begin{aligned}
& \Delta_{\alpha, \beta} \phi\left(\mathrm{Cat}_{v_{\mathrm{Cat}}}^{\left(z_{\mathrm{Cat}}\right)+} \mathrm{An}_{v_{\mathrm{An}}}^{\left(z_{\mathrm{An}}\right)-}\right) \\
& =\frac{z_{\mathrm{Cat}} \Delta_{\alpha, \beta} \phi_{\mathrm{Cat}}^{\ominus}{ }^{\left(z_{\mathrm{Cat}}\right)+}+\left|z_{\mathrm{An}}\right| \Delta_{\alpha, \beta} \phi_{\mathrm{An}^{\left(z_{\mathrm{An}}\right)}-}^{\ominus}}{\left(z_{\mathrm{Cat}}+\left|z_{\mathrm{An}}\right|\right)}
\end{aligned}
$$

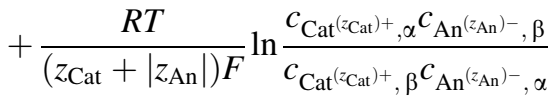

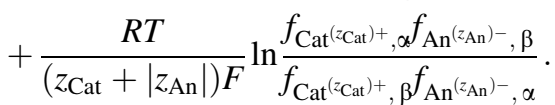

From the stoichiometry of the salt $\mathrm{Cat}_{v_{\text {Cat }}}^{\left(z_{\mathrm{Cat}}\right)+} \mathrm{An}_{v_{\mathrm{An}}}^{\left(z_{\mathrm{An}}\right)-}$ it follows that in the bulk of the two phases the conditions $c_{\mathrm{Cat}}{ }^{\left(z_{\mathrm{Cat}}\right)+, \beta}=\frac{v_{\mathrm{Cat}}}{v_{\mathrm{An}}} c_{\mathrm{An}{ }^{\left(z_{\mathrm{An}}\right)-}, \beta}$ and $\quad c_{\mathrm{Cat}}{ }^{\left(z_{\mathrm{Cat}}\right)+, \alpha}=\frac{v_{\mathrm{Cat}}}{v_{\mathrm{An}}} c_{\mathrm{An}^{\left(z_{\mathrm{An}}\right)-}, \alpha}$ hold true. With these relations follows 


$$
\begin{aligned}
& \Delta_{\alpha, \beta} \phi\left(\mathrm{Cat}_{{ }^{\mathrm{Cat}}}^{\left(\mathrm{Z}_{\mathrm{Cat}}\right)+} \mathrm{An}_{v_{\mathrm{An}}}^{\left(z_{\mathrm{An}}\right)-}\right) \\
& =\frac{z_{\mathrm{Cat}} \Delta_{\alpha, \beta} \phi_{\mathrm{Cat}^{\left(z_{\mathrm{Cat}}\right)+}}^{\ominus}+\left|z_{\mathrm{An}}\right| \Delta_{\alpha, \beta} \phi_{\mathrm{An}^{\left(z_{\mathrm{An}}\right)-}}^{\ominus}}{\left(z_{\mathrm{Cat}}+\left|z_{\mathrm{An}}\right|\right)}
\end{aligned}
$$

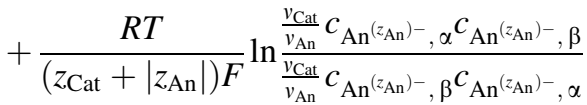

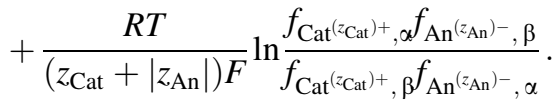

Since the second term on the right side of Eq. (41) equals zero, the final equation is

$$
\begin{aligned}
& \Delta_{\alpha, \beta} \phi\left(\mathrm{Cat}_{{ }^{\mathrm{Cat}}}^{\left(\mathrm{ZCat}^{\mathrm{Cat}}\right)+} \mathrm{An}_{v_{\mathrm{An}}}^{\left(\mathrm{z}_{\mathrm{An}}\right)-}\right) \\
& =\frac{z_{\mathrm{Cat}} \Delta_{\alpha, \beta} \phi_{\mathrm{Cat}^{\left(z_{\mathrm{Cat}}\right)+}}^{\ominus}+\left|z_{\mathrm{An}}\right| \Delta_{\alpha, \beta} \phi_{\mathrm{An}^{\left(z_{\mathrm{An}}\right)-}}^{\ominus}}{\left(z_{\mathrm{Cat}}+\left|z_{\mathrm{An}}\right|\right)} \\
& +\frac{R T}{\left(z_{\mathrm{Cat}}+\left|z_{\mathrm{An}}\right|\right) F} \ln \frac{f_{\mathrm{Cat}^{\left(z_{\mathrm{Cat}}\right)+},{ }_{\alpha}} f_{\mathrm{An}^{\left(z_{\mathrm{An}}\right)-}, \beta}}{f_{\mathrm{Cat}^{\left(z_{\mathrm{Cat}}\right)+}, \beta} f_{\mathrm{An}^{\left(z_{\mathrm{An}}\right)-}, \alpha}} .
\end{aligned}
$$

Equation (40) can be also applied to the solubility of a salt, when this is considered as the result of distributing the cations and anions between the solid salt phase and the saturated solution: see Sect. "Distribution of ions between the solid salt phase and the salt saturated solution".

For very diluted systems, the activity coefficients approach unity, and then the last term in Eq. (42) also vanishes, and the overall Galvani potential difference

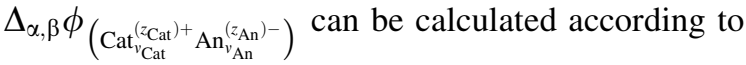

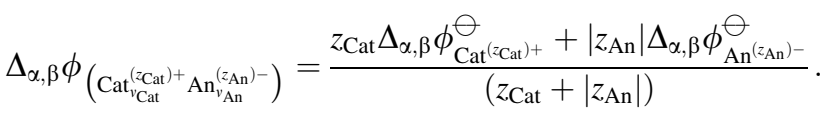

To calculate the partition constant of the salt $K_{\mathrm{p}\left(\mathrm{Cat}_{v_{\mathrm{Cat}}}^{\left(z_{\mathrm{Cat}}\right)+} \mathrm{An}_{v_{\mathrm{An}}}^{\left(z_{\mathrm{An}}\right)-}\right), T, p}$, the partition constants of cations and anions must be used in Eq. 16:

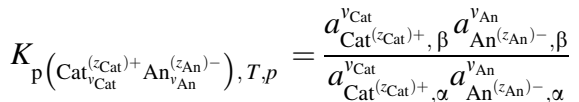

$$
\begin{aligned}
& =\left(K_{\mathrm{p}\left(\mathrm{Cat}^{\left.\left({ }^{2} \mathrm{Cat}\right)^{+}\right)}, T, p\right.}\right)^{v_{\mathrm{Cat}}}\left(K_{\mathrm{p}\left(\mathrm{An}^{\left(\mathrm{z}_{\mathrm{An}}\right)-}\right), T, p}\right)^{v_{\mathrm{An}}},
\end{aligned}
$$$$
\begin{aligned}
\ln K_{\mathrm{p}}\left(\mathrm{Cat}_{{ }^{\mathrm{Cat}}}^{\left({ }_{\mathrm{Cat}}{ }^{\mathrm{Cat}}\right)+} \mathrm{An}_{v_{\mathrm{An}}}^{\left(z_{\mathrm{An}}\right)-}\right), T, p= & v_{\mathrm{Cat}} \ln K_{\left.\mathrm{p}\left(\mathrm{Cat}^{\left({ }^{2} \mathrm{Cat}\right.}\right)^{+}\right), T, p} \\
& +v_{\mathrm{An}} \ln K_{\mathrm{p}\left(\mathrm{An}^{\left({ }_{\mathrm{An}}\right)-}\right), T, p} .
\end{aligned}
$$

For the cations, we can formulate Eq. (29) according to

$\ln K_{\mathrm{p}\left(\mathrm{Cat}^{\left.\left({ }^{\mathrm{Cat}}\right)^{+}\right), T, p}\right.}=\frac{z_{\mathrm{Cat}} F}{R T} \Delta_{\alpha, \beta} \phi_{\mathrm{Cat}^{\left(z^{\mathrm{Cat}}\right)+}}^{\ominus}$

and for the anions

$\ln K_{\mathrm{p}\left(\mathrm{An}^{\left.\left(z_{\mathrm{An}}\right)^{-}\right), T, p}\right.}=\frac{z_{\mathrm{An}} F}{R T} \Delta_{\alpha, \beta} \phi_{\mathrm{An}^{\left(z_{\mathrm{An}}\right)-}}^{\ominus}$.
Inserting Eqs. (45) and (46) in Eq. (44) gives

$$
\begin{aligned}
\ln K_{\mathrm{p}\left(\mathrm{Cat}_{v_{\mathrm{Cat}}}^{\left(z_{\mathrm{Cat}}\right)+}\right.} \operatorname{An}_{\left.v_{\mathrm{An}}^{\left(z_{\mathrm{An}}\right)-}\right), T, p}= & v_{\mathrm{Cat}} \frac{z_{\mathrm{Cat}} F}{R T} \Delta_{\alpha, \beta} \phi_{\mathrm{Cat}^{\left(z_{\mathrm{Cat}}\right)+}}^{\ominus} \\
& +v_{\mathrm{An}} \frac{z_{\mathrm{An}} F}{R T} \Delta_{\alpha, \beta} \phi_{\mathrm{An}^{\left(z_{\mathrm{An}}\right)-}}^{\ominus} .
\end{aligned}
$$

Since $v_{\mathrm{Cat}}=\left|z_{\mathrm{An}}\right|$ and $v_{\mathrm{An}}=z_{\mathrm{Cat}}$, and $z_{\mathrm{An}}$ in the second term on the right side has a negative sign, it finally follows

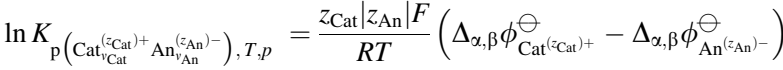

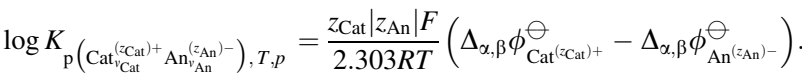

It is interesting to remember that Eq. (48) has the same structure as that for calculating the equilibrium constant of a redox reaction $v_{1} \operatorname{Red}_{1}+v_{2} \mathrm{Ox}_{2} \rightleftarrows v_{1} \mathrm{Ox}_{1}+v_{2} \operatorname{Red}_{2}$ with the two redox equilibria $\mathrm{Ox}_{1}+n_{1} \mathrm{e}^{-} \rightleftarrows \operatorname{Red}_{1}$ and $\mathrm{Ox}_{2}+n_{2} \mathrm{e}^{-} \rightleftarrows \operatorname{Red}_{2}$, where the relation $v_{1} n_{1}=v_{2} n_{2}=z$ holds, and the equilibrium constant is $\ln K=\frac{z F}{R T}\left(E_{\mathrm{Ox}_{2} / \operatorname{Red}_{2}}^{\ominus}-E_{\mathrm{Ox}_{1} / \operatorname{Red}_{1}}^{\ominus}\right) \quad$ or $\quad \log K=z \frac{F}{2.303 R T}$ $\left(E_{\mathrm{Ox}_{2} / \operatorname{Red}_{2}}^{\ominus}-E_{\mathrm{Ox}_{1} / \operatorname{Red}_{1}}^{\ominus}\right)$ [6]. These equations are similar because in both cases two interdependent equilibria determine the overall equilibrium.

In the case of a uni-univalent salt $\mathrm{Cat}^{+} \mathrm{An}^{-}$, it follows for $\Delta_{\alpha, \beta} \phi_{\left(\mathrm{Cat}^{+} \mathrm{An}^{-}\right)}$

$\Delta_{\alpha, \beta} \phi_{\left(\mathrm{Cat}^{+} \mathrm{An}^{-}\right)}=\frac{\Delta_{\alpha, \beta} \phi_{\mathrm{Cat}^{+}}^{\ominus}+\Delta_{\alpha, \beta} \phi_{\mathrm{An}^{-}}^{\ominus}}{2}$

and for $K_{\mathrm{p}\left(\mathrm{Cat}^{+}{ }^{+} \mathrm{An}^{-}\right), T, p}=\frac{a_{\mathrm{Cat}^{+}, \beta} a_{\mathrm{An}^{-}, \beta}}{a_{\mathrm{Cat}^{+}, \alpha} a_{\mathrm{An}^{-}, \alpha}}$

$$
\begin{aligned}
& \ln K_{\mathrm{p}\left(\mathrm{Cat}^{+} \mathrm{An}^{-}\right), T, p}=\frac{F}{R T}\left(\Delta_{\alpha, \beta} \phi_{\mathrm{Cat}^{+}}^{\ominus}-\Delta_{\alpha, \beta} \phi_{\mathrm{An}^{-}}^{\ominus}\right) \\
& \log K_{\mathrm{p}\left(\mathrm{Cat}^{+} \mathrm{An}^{-}\right), T, p}=\frac{F}{2.303 R T}\left(\Delta_{\alpha, \beta} \phi_{\mathrm{Cat}^{+}}^{\ominus}-\Delta_{\alpha, \beta} \phi_{\mathrm{An}^{-}}^{\ominus}\right) .
\end{aligned}
$$

Figures 2 and 3 illustrate how a lipophilic anion, here $\mathrm{TPB}^{-}$can affect the partition of a hydrophilic cation, here $\mathrm{K}^{+}$; whereas $\mathrm{K}^{+} \mathrm{Cl}^{-}$has a partition constant $\log K_{\mathrm{p}\left(\mathrm{K}^{+} \mathrm{Cl}^{-}\right), T, p}=-9.5$, the partition constant of $\mathrm{K}^{+} \mathrm{TPB}^{-}$ is $\log K_{\mathrm{p}\left(\mathrm{K}^{+} \mathrm{TPB}^{-}\right), T, p}=2.3$, i.e. the potassium concentration in nitrobenzene is much larger when $\mathrm{K}^{+} \mathrm{TPB}^{-}$is partitioned than in the case of $\mathrm{K}^{+} \mathrm{Cl}^{-}$.

Figure 4 illustrates how the chemical affinities of the anions and cations for the two phases conflict with the necessity of electroneutrality in each phase. The result is a compromise, a trade-off reflecting the (mostly) different affinities of the anions and cations, so that electroneutrality in the bulk phases is maintained. One may say that the cations partition in such way that they-to some extent 
Fig. 2 a Standard Galvani potentials of ion transfer of $\mathrm{K}^{+}$, $\mathrm{Cl}^{-}$and $\mathrm{TPB}^{-}$

(tetraphenylborate), b standard

Galvani potentials of salt

partition of $\mathrm{K}^{+} \mathrm{Cl}^{-}$and

$\mathrm{K}^{+} \mathrm{TPB}^{-}$, and (see Eq. 43) $\mathrm{c} \log$ partition constants of $\mathrm{K}^{+} \mathrm{Cl}^{-}$ and $\mathrm{K}^{+} \mathrm{TPB}^{-}$, for the system water-nitrobenzene
(A)

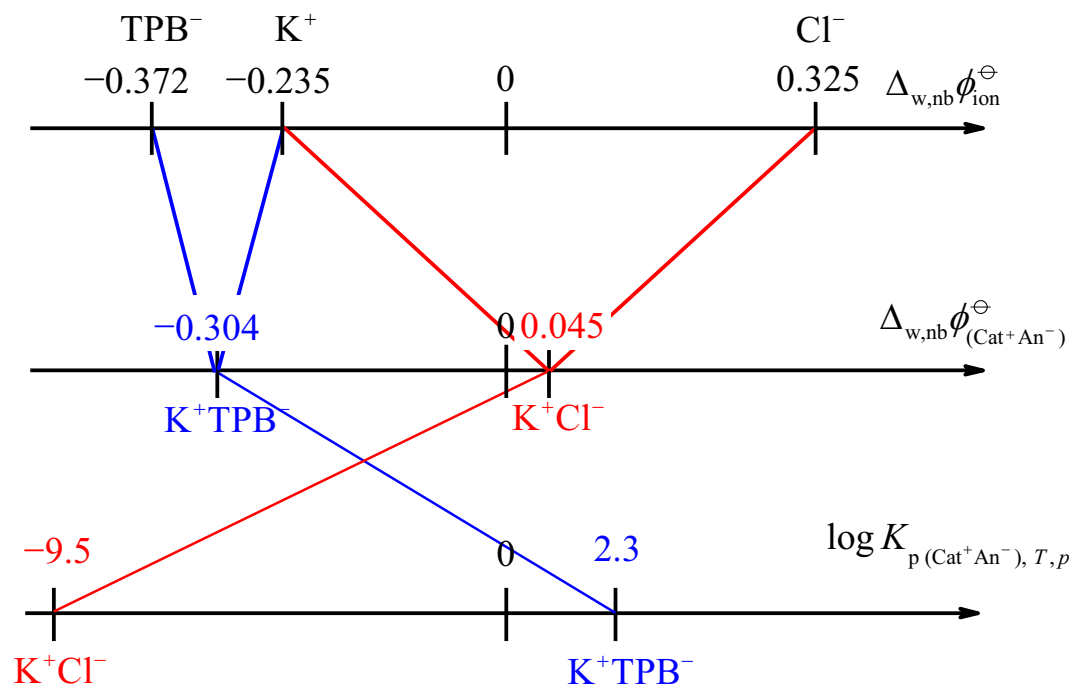

(A)

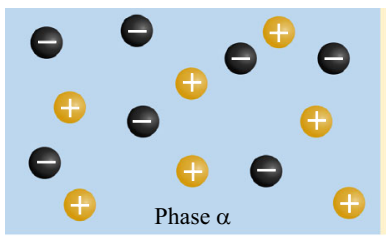

(B)

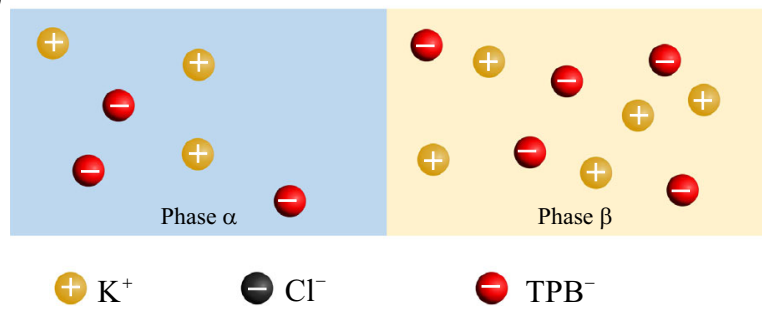

Fig. 3 Illustration of the partition of $\mathbf{a ~} \mathrm{KCl}$ between water (phase $\alpha$ ) and nitrobenzene (phase $\beta$ ), b KTPB between water and nitrobenzene

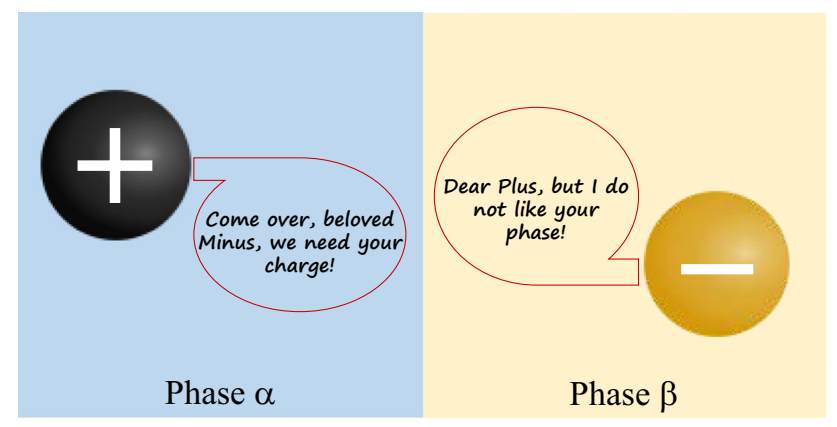

Fig. 4 Cartoon illustrating how the different affinities of cations and anions for the two phases conflict with the condition of electroneutrality in the bulk phases

- "respect" the affinity of the anions, and vice versa. This compromise leads (i) to a potential difference at the

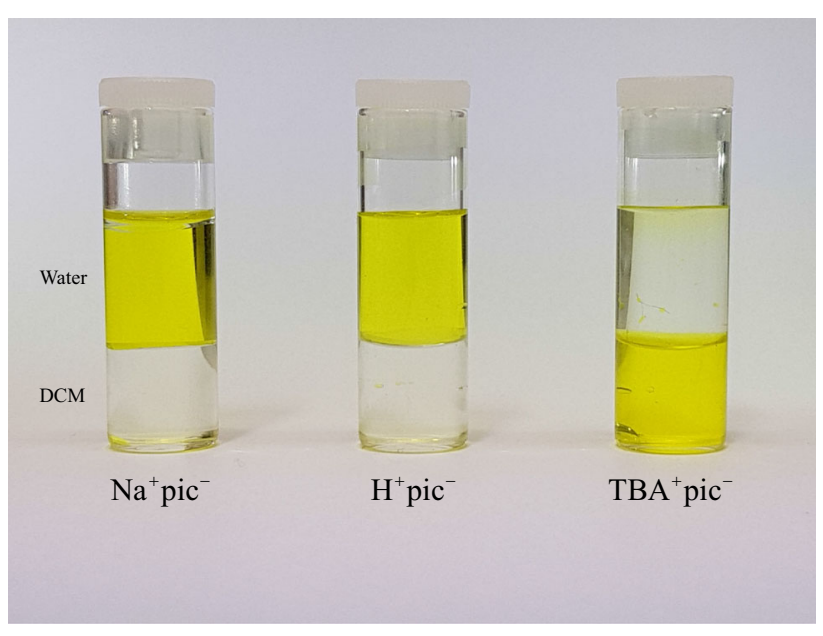

Fig. 5 Partition of sodium picrate $\left(\mathrm{Na}^{+} \mathrm{pic}^{-}\right)$, picric acid $\left(\mathrm{H}^{+} \mathrm{pic}^{-}\right)$ and tetrabutylammonioum picrate $\left(\mathrm{TBA}^{+} \mathrm{pic}^{-}\right)$between water and dichloromethane (DCM)

interface (if the affinities are not equal, as in the case of the example $\mathrm{TPA}^{+} \mathrm{TPB}^{-}$) and (ii) to different concentrations of the salt in both phases (if the affinities are not identical).

The tuning of partition constants of salts by choosing appropriate combinations of cations and anions is illustrated in Fig. 5: picric acid (2,4,6-trinitrophenol) is a relatively strong acid in aqueous solution $\left(\mathrm{p} K_{\mathrm{a}}\right.$ around 0.4$)$. Although the picrate anion (2,4,6-trinitrophenolate) is rather hydrophobic, the partition of sodium picrate $\left(\mathrm{Na}^{+} \mathrm{pic}^{-}\right)$between water and dichloromethane (DCM) is such that the salt almost completely stays in water. The partition constant is $K_{\mathrm{p}\left(\mathrm{Na}^{+} \mathrm{pic}^{-}\right), \mathrm{w}-\mathrm{DCM}}=\frac{a_{\left(\mathrm{Na}^{+} \mathrm{pic}^{-}\right), \mathrm{DCM}}}{a_{\left(\mathrm{Na}^{+} \mathrm{pic}^{-}\right), \mathrm{water}}}$ $=2.5 \times 10^{-5}$ [7]. This is illustrated by Fig. 5 , where the aqueous phase is strongly yellow, the colour of picrate ions, whereas the DCM phase is colourless. The same result is obtained for the partition of picric acid (see Fig. 5) 
because the transfer of protons to the DCM phase is strongly disfavoured. However, when the sodium ions are substituted by the rather hydrophobic tetrabutylammonium $\left(\mathrm{TBA}^{+}\right)$cation, the partition strongly favours the presence of picrate in DCM. Figure 5 shows for the partition of $\mathrm{TBA}^{+}$pic $^{-}$a yellow DCM phase and a colourless aqueous phase. In fact, the partition of picrates is not as simple as presented here: in DCM, the formation of ion pairs has to be taken into account. The formation constant of the ion pairs $\left[\mathrm{TBA}^{+} \mathrm{pic}^{-}\right]$in water-saturated $\mathrm{DCM}$ is rather large: $\log K_{\mathrm{IP}\left[\mathrm{TBA}^{+} \text {pic }^{-}\right] \text {,DMC }}=3.82 \pm 0.06$. The formation constant of $\left[\mathrm{TBA}^{+} \mathrm{pic}^{-}\right]$in water is comparably small $\left(\log K_{\mathrm{IP}\left[\mathrm{TBA}^{+} \text {pic }^{-}\right], \mathrm{w}}=1.033 \pm 0.008\right)$. The partition constant of $\mathrm{TBA}^{+} \mathrm{pic}^{-}$for water-DCM is $\log K_{\mathrm{p}\left(\mathrm{TBA}^{+} \mathrm{pic}^{-}\right) \text {, }-\mathrm{DCM}}=5.52 \pm 0.03$ (all data from [8]), which is clearly a result of the hydrophobic nature of $\mathrm{TBA}^{+}$, as well as of the favourable ion pair formation in DCM.

\section{Experimental considerations concerning the partition of a salt between two immiscible solution phases}

The partition constants of neutral molecules are experimentally accessible without any principal constraints. It is just necessary to have analytical techniques at hand, allowing the determination of the concentration of the partitioned compound in both phases. For salts, this can be done in the same way; however, the individual partition constants of the anions and cations are not so easily accessible. Since the individual partition constants are a measure of the interaction of the individual ions with each of the two solvents, e.g. with water and the organic solvent, it is important to know these data. They provide information about the hydrophilicity/hydrophobicity and oleophilicity/oleophobicity of the ions!

Let us consider a uni-univalent salt, for which $K_{\mathrm{p}\left(\mathrm{Cat}^{+}{ }^{+} \mathrm{An}^{-}\right), T, p}=\frac{a_{\mathrm{Cat}^{+}, \beta} a_{\mathrm{An}^{-}, \beta}}{a_{\mathrm{Cat}^{+}, \alpha} a_{\mathrm{An}^{-}, \alpha}} \approx \frac{c_{\mathrm{Cat}^{+}, \beta} c_{\mathrm{An}^{-}, \beta}}{c_{\mathrm{Cat}^{+}, \alpha} c_{\mathrm{An}^{-}, \alpha}}$ is experimentally accessible by measuring the concentrations $c_{\left(\mathrm{Cat}^{+} \mathrm{An}^{-}\right), \alpha}$ and $c_{\left(\mathrm{Cat}^{+} \mathrm{An}^{-}\right), \beta}$. According to Eq. (44) the relation for a uniunivalent salt is

$\ln K_{\mathrm{p}\left(\mathrm{Cat}^{+} \mathrm{An}^{-}\right), T, p}=\ln K_{\mathrm{p}\left(\mathrm{Cat}^{+}\right), T, p}+\ln K_{\mathrm{p}\left(\mathrm{An}^{-}\right), T, p}$.

When $K_{\mathrm{p}\left(\mathrm{Cat}^{+} \mathrm{An}^{-}\right), T, p}$ is determined by measuring the salt concentrations in both phases, the partition constant of either the cation must be known to calculate that of the anions, or vice versa. This is a serious problem which can be solved only by making for some salts the extrathermodynamic (i.e. not strictly based on thermodynamics) assumptions that the partition coefficients are identical for the anion and cation. This is reasonable in the case of very bulky organic ions, e.g. tetraphenylarsonium $\left(\mathrm{TBA}^{+}\right)$ cations and tetraphenylborate $\left(\mathrm{TPB}^{-}\right)$anions. The latter salt was first proposed by Grunwald et al. [5]. On the basis of this extrathermodynamic assumption, it is possible to build up a system of consistent $K_{\mathrm{p}\left(\mathrm{Cat}^{+}\right), T, p}$ and $K_{\mathrm{p}\left(\mathrm{An}^{-}\right), T, p}$ data from analysis of the salt concentrations in the two phases, when different salt combinations are used, among which are salts with $\mathrm{TBA}^{+}$cations and $\mathrm{TPB}^{-}$anions.

The experimental determination of individual ion partition constants can also be achieved with the help of electrochemistry. Dating back to first experiments by Nernst and Riesenfeld [9], now voltammetric techniques [10] are available with which the individual transfer of ions across liquid-liquid interfaces can be measured, and from the characteristic potentials of the voltammograms, the standard potentials of the individual ions can be estimated, of course always relying on an extrathermodynamic assumption, like the mentioned Grunwald assumption [11-14]. These measurements need a four-electrode potentiostat, and they are rather limited with respect to the solvent systems. There exists another electrochemical approach, where an electrochemically generated redox probe drives an ion transfer across a liquid-liquid interface [15-17]. For this, a three-electrode potentiostat is sufficient and the number of solvent systems is considerably larger. A complete discussion of the experimental approaches to measure the individual transfer of ions (i.e. ion partition) cannot be given here, and the interested reader should consult the mentioned sources.

\section{Distribution of ions between the solid salt phase and the salt saturated solution}

The solubility of a sparingly soluble salt can be considered as the result of distributing the cations and anion between the solid salt phase (s) and the saturated solution (sol):

$\mathrm{Cat}_{\mathrm{s}}^{+}+\mathrm{An}_{\mathrm{s}}^{-} \rightleftarrows \mathrm{Cat}_{\mathrm{sol}}^{+}+\mathrm{An}_{\mathrm{sol}}^{-}$

(Equilibrium III)

Of course, $\mathrm{Cat}_{\mathrm{s}}^{+}$and $\mathrm{An}_{\mathrm{s}}^{-}$build up the solid phase $\left\{\mathrm{Cat}^{+} \mathrm{An}^{-}\right\}_{\mathrm{s}}$. Equilibrium III has the following equilibrium constant:

$K_{\mathrm{p}\left(\mathrm{Cat}^{+} \mathrm{An}^{-}\right), T, p}=\frac{a_{\mathrm{Cat}^{+}, \mathrm{sol}} a_{\mathrm{An}^{-}, \mathrm{sol}}}{a_{\mathrm{Cat}^{+}, \mathrm{s}} a_{\mathrm{An}^{-}, \mathrm{s}}}$.

The exact quantity of the activities of the ions in the solid are not known; however, it is clear that they are constant. The solubility product $K_{\mathrm{sp}\left(\mathrm{Cat}^{+} \mathrm{An}^{-}\right), T, p}$ of the salt is

$K_{\mathrm{sp}\left(\mathrm{Cat}^{+} \mathrm{An}^{-}\right), T, p}=a_{\mathrm{Cat}^{+}, \mathrm{sol}} a_{\mathrm{An}^{-}, \mathrm{sol}}$,

and this is the relation between the solubility product and the partition constant: 
$K_{\mathrm{sp}\left(\mathrm{Cat}^{+}{ }^{-}{ }^{-}\right), T, p}=K_{\mathrm{p}\left(\mathrm{Cat}^{+} \mathrm{An}^{-}\right), T, p} a_{\mathrm{Cat}^{+}{ }_{\mathrm{s}}} a_{\mathrm{An}^{-}, \mathrm{s}}$.

For the cations, Eq. (26) can be written as follows:

$$
\begin{aligned}
\Delta_{\mathrm{s}, \mathrm{sol}} \phi_{\mathrm{Cat}^{+}} & =\Delta_{\mathrm{s}, \mathrm{sol}} \phi_{\mathrm{Cat}^{+}}^{\ominus}+\frac{R T}{F} \ln \frac{a_{\mathrm{Cat}^{+}, \mathrm{s}}}{a_{\mathrm{Cat}^{+}, \mathrm{sol}}} \\
& =\Delta_{\mathrm{s}, \mathrm{sol}} \phi_{\mathrm{Cat}^{+}}^{\ominus}+\frac{R T}{F} \ln a_{\mathrm{Cat}^{+}, \mathrm{s}}-\frac{R T}{F} \ln a_{\mathrm{Cat}^{+}, \mathrm{sol}} .
\end{aligned}
$$

The first and second terms on the right side of the equation can be combined to the formal potential of the cation transfer $\Delta_{\mathrm{s}, \mathrm{sol}} \phi_{\mathrm{c}, \mathrm{Cat}^{+}}^{\ominus^{\prime}}=\Delta_{\mathrm{s}, \mathrm{sol}} \phi_{\mathrm{Cat}^{+}}^{\ominus}+\frac{R T}{F} \ln a_{\mathrm{Cat}^{+}, \mathrm{s}}$ (the subscript c of $\Delta_{\mathrm{s}, \mathrm{sol}} \phi_{\mathrm{c}, \mathrm{Cat}^{+}}^{\ominus^{\prime}}$ stands for 'conditional' because formal potentials relate to fixed conditions), and thus:

$\Delta_{\mathrm{s}, \mathrm{sol}} \phi_{\mathrm{Cat}^{+}}=\Delta_{\mathrm{s}, \mathrm{sol}} \phi_{\mathrm{c}, \mathrm{Cat}^{+}}^{\ominus^{\prime}}-\frac{R T}{F} \ln a_{\mathrm{Cat}^{+}, \mathrm{sol}} \cdot$

For the anions, Eq. (26) is

$$
\begin{aligned}
\Delta_{\mathrm{s}, \mathrm{sol}} \phi_{\mathrm{An}^{-}} & =\Delta_{\mathrm{s}, \mathrm{sol}} \phi_{\mathrm{An}^{-}}^{\ominus}-\frac{R T}{F} \ln \frac{a_{\mathrm{An}^{-}, \mathrm{s}}}{a_{\mathrm{An}^{-}, \mathrm{sol}}} \\
& =\Delta_{\mathrm{s}, \mathrm{sol}} \phi_{\mathrm{Cat}^{+}}^{\ominus}-\frac{R T}{F} \ln a_{\mathrm{An}^{-}, \mathrm{s}}+\frac{R T}{F} \ln a_{\mathrm{An}^{-}, \mathrm{sol}} .
\end{aligned}
$$

The formal potential of the anion transfer is $\Delta_{\mathrm{s}, \mathrm{sol}} \phi_{\mathrm{c}, \mathrm{An}^{-}}^{\ominus}=\Delta_{\mathrm{s}, \mathrm{sol}} \phi_{\mathrm{An}^{-}}^{\ominus}-\frac{R T}{F} \ln a_{\mathrm{An}^{-}, \mathrm{s}}$. With that follows

$\Delta_{\mathrm{s}, \mathrm{sol}} \phi_{\mathrm{An}^{-}}=\Delta_{\mathrm{s}, \mathrm{sol}} \phi_{\mathrm{c}, \mathrm{An}^{-}}^{\ominus^{\prime}}+\frac{R T}{F} \ln a_{\mathrm{An}^{-}, \mathrm{sol}}$.

Like at the liquidlliquid interface, also here only one Galvani potential difference can be established: $\Delta_{\mathrm{s}, \mathrm{sol}} \phi_{\mathrm{Cat}^{+}}=\Delta_{\mathrm{s}, \mathrm{sol}} \phi_{\mathrm{An}^{-}}=\Delta_{\mathrm{s}, \mathrm{sol}} \phi_{\left(\mathrm{Cat}^{+} \mathrm{An}^{-}\right)}$. Summing up Eqs. (55) and (57), and substituting activities with the products of activity coefficients and concentrations allows one to calculate $\Delta_{\mathrm{s}, \mathrm{sol}} \phi_{\left(\mathrm{Cat}^{+} \mathrm{An}^{-}\right)}$:

$$
\begin{aligned}
\Delta_{\mathrm{s}, \mathrm{sol}} \phi_{\left(\mathrm{Cat}^{+} \mathrm{An}^{-}\right)}= & \frac{\Delta_{\mathrm{s}, \mathrm{sol}} \phi_{\mathrm{c}, \mathrm{Cat}^{+}}^{\ominus^{\prime}}+\Delta_{\mathrm{s}, \mathrm{sol}} \phi_{\mathrm{c}, \mathrm{An}^{-}}^{\ominus^{\prime}}}{2} \\
& +\frac{R T}{2 F} \ln \frac{f_{\mathrm{An}^{-}, \mathrm{sol}}}{f_{\mathrm{Cat}^{+}, \mathrm{sol}}}+\frac{R T}{2 F} \ln \frac{c_{\mathrm{An}^{-}, \mathrm{sol}}}{c_{\mathrm{Cat}^{+}, \mathrm{sol}}}, \\
\Delta_{\mathrm{s}, \mathrm{sol}} \phi_{\left(\mathrm{Cat}^{+} \mathrm{An}^{-}\right)} \approx & \frac{\Delta_{\mathrm{s}, \mathrm{sol}} \phi_{\mathrm{c}, \mathrm{Cat}^{+}}^{\ominus^{\prime}}+\Delta_{\mathrm{s}, \mathrm{sol}} \phi_{\mathrm{c}, \mathrm{An}^{-}}^{\ominus^{\prime}}}{2} \\
& +\frac{R T}{2 F} \ln \frac{c_{\mathrm{An}^{-}, \mathrm{sol}}}{c_{\mathrm{Cat}^{+}, \mathrm{sol}}} .
\end{aligned}
$$

For the saturated solution of the pure sparingly soluble salt, the concentration of the cations equals the concentration of the anions (no excess of one ion sort) in the solution.

In the equilibrium, $\Delta_{\mathrm{s}, \mathrm{sol}} \phi_{\left(\mathrm{Cat}^{+} \mathrm{An}^{-}\right)}$must be zero, because in both phases an excess of cations or anions does not exist.
It can be also shown that $\Delta_{\mathrm{s}, \mathrm{sol}} \phi_{\left(\mathrm{Cat}^{+} \mathrm{An}^{-}\right)}$is zero, when the following relations are considered: Defining the two partition constants $K_{\mathrm{p}, \mathrm{Cat}^{+}}=\frac{a_{\mathrm{Cat}^{+}, \mathrm{sol}}}{a_{\mathrm{Cat}^{+}, \mathrm{s}}}$ and $K_{\mathrm{p}, \mathrm{An}^{-}}=\frac{a_{\mathrm{An}^{-}, \mathrm{sol}}}{a_{\mathrm{An}^{-}, \mathrm{s}}}$ and taking into account that the activities in the solid are constant (although not necessarily equal) gives $a_{\mathrm{Cat}^{+}{ }, \text {sol }}=$ $\sqrt{K_{\mathrm{sp}}}=K_{\mathrm{p}, \mathrm{Cat}^{+}} a_{\mathrm{Cat}^{+}, \mathrm{s}}$ and $a_{\mathrm{An}^{-}, \mathrm{sol}}=\sqrt{K_{\mathrm{sp}}}=K_{\mathrm{p}, \mathrm{An}^{-}} a_{\mathrm{An}^{-}, \mathrm{s}}$. Using the relation between equilibrium constants and the formal Galvani potentials yields $R T \ln \left(K_{\mathrm{p}, \mathrm{Cat}^{+}} a_{\left.\mathrm{Cat}^{+}{ }_{\mathrm{s}}\right)}\right)=$ $F \Delta_{\mathrm{s}, \mathrm{sol}} \phi_{\mathrm{c}, \mathrm{Cat}^{+}}^{\ominus^{\prime}}=R T \ln \sqrt{K_{\mathrm{sp}}} \quad$ and $R T \ln \left(K_{\mathrm{p}, \mathrm{An}^{-}} a_{\mathrm{An}^{-}, \mathrm{s}}\right)=$ $-F \Delta_{\mathrm{s}, \mathrm{sol}} \phi_{\mathrm{c}, \mathrm{An}^{-}}^{\bigcirc^{\prime}}=R T \ln \sqrt{K_{\mathrm{sp}}}$. This means that the relation $F \Delta_{\mathrm{s}, \mathrm{sol}} \phi_{\mathrm{c}, \mathrm{Cat}^{+}}^{\ominus^{\prime}}=-F \Delta_{\mathrm{s}, \mathrm{sol}} \phi_{\mathrm{c}, \mathrm{An}^{-}}^{\ominus^{\prime}}$ holds true, i.e. $\Delta_{\mathrm{s}, \mathrm{sol}} \phi_{\mathrm{c}, \mathrm{Cat}^{+}}^{\ominus^{\prime}}+\Delta_{\mathrm{s}, \mathrm{sol}} \phi_{\mathrm{c}, \mathrm{An}^{-}}^{\ominus^{\prime}}=0$. Hence, in Eq. (59) both terms of the right side are zero and thus $\Delta_{\mathrm{s}, \mathrm{sol}} \phi_{\left(\mathrm{Cat}^{+} \mathrm{An}^{-}\right)}$is also zero. The partition constants $K_{\mathrm{p}, \mathrm{Cat}^{+}}$and $K_{\mathrm{p}, \mathrm{An}^{-}}$are defined for a zero potential difference, as was done in the case of the partition constants of ions between two liquid phases; see discussion following Eq. (26). Hence, it is not surprising that in the end a zero potential difference results, but it shows that the entire description is consistent.

If the concentration of the cations or anions in the solution is changed by addition of a salt containing the same cation or anion (e.g. by addition of silver nitrate or sodium chloride to the saturated solution of silver chloride), a potential difference at the saltlsolution interface builds up. Since the term $\frac{\Delta_{\mathrm{s}, \mathrm{sol}} \phi_{\mathrm{c}, \mathrm{Cat}}^{\ominus^{\prime}}+\Delta_{\mathrm{s}, \mathrm{sol}} \phi_{\mathrm{c}, \mathrm{An}}^{\ominus^{\prime}}}{2}$ in Eq. (59) is zero, but the anion and cation concentrations are no longer equal, this equation can be used to calculate the potential difference at the saltlsolution interface:

$\Delta_{s, \text { sol }} \phi_{\left(\mathrm{Cat}^{+} \mathrm{An}^{-}\right)}=\frac{R T}{2 F} \ln \frac{c_{\mathrm{An}^{-}, \mathrm{sol}}}{c_{\mathrm{Cat}^{+}, \mathrm{sol}}}+\frac{R T}{2 F} \ln \frac{f_{\mathrm{An}^{-}, \mathrm{sol}}}{f_{\mathrm{Cat}^{+}, \mathrm{sol}}}$

When anion addition is considered, the concentration $c_{\mathrm{Cat}^{+} \text {,sol }}$ can be substituted by

$c_{\mathrm{Cat}^{+}, \mathrm{sol}}=\frac{K_{\mathrm{sp}}}{c_{\mathrm{An}^{-}, \mathrm{sol}}}$.

Inserting Eq. (61) in Eq. (60) gives

$\Delta_{\mathrm{s}, \mathrm{sol}} \phi_{\left(\mathrm{Cat}^{+} \mathrm{An}^{-}\right)}=\frac{R T}{2 F} \ln \frac{c_{\mathrm{An}^{-}, \mathrm{sol}}^{2}}{K_{\mathrm{sp}}}+\frac{R T}{2 F} \ln \frac{f_{\mathrm{An}^{-}, \mathrm{sol}}}{f_{\mathrm{Cat}^{+}, \mathrm{sol}}}$.

Equation (62) nicely shows that the potential difference at the saltlsolution interface $\Delta_{\mathrm{s}, \mathrm{sol}} \phi_{\left(\mathrm{Cat}^{+} \mathrm{An}^{-}\right)}=\phi_{\text {sol, }\left(\mathrm{Cat}^{+} \mathrm{An}^{-}\right)}$ $-\phi_{\mathrm{s},\left(\mathrm{Cat}^{+} \mathrm{An}^{-}\right)}$becomes positive. In the case of addition of the cations to the solution (e.g. addition of silver nitrate to the saturated solution of silver chloride), the potential difference is

$\Delta_{\mathrm{s}, \mathrm{sol}} \phi_{\left(\mathrm{Cat}^{+} \mathrm{An}^{-}\right)}=\frac{R T}{2 F} \ln \frac{K_{\mathrm{sp}}}{c_{\mathrm{Cat}^{+}, \mathrm{sol}}^{2}}+\frac{R T}{2 F} \ln \frac{f_{\mathrm{An}^{-}, \mathrm{sol}}}{f_{\mathrm{Cat}^{+}, \mathrm{sol}}}$, 

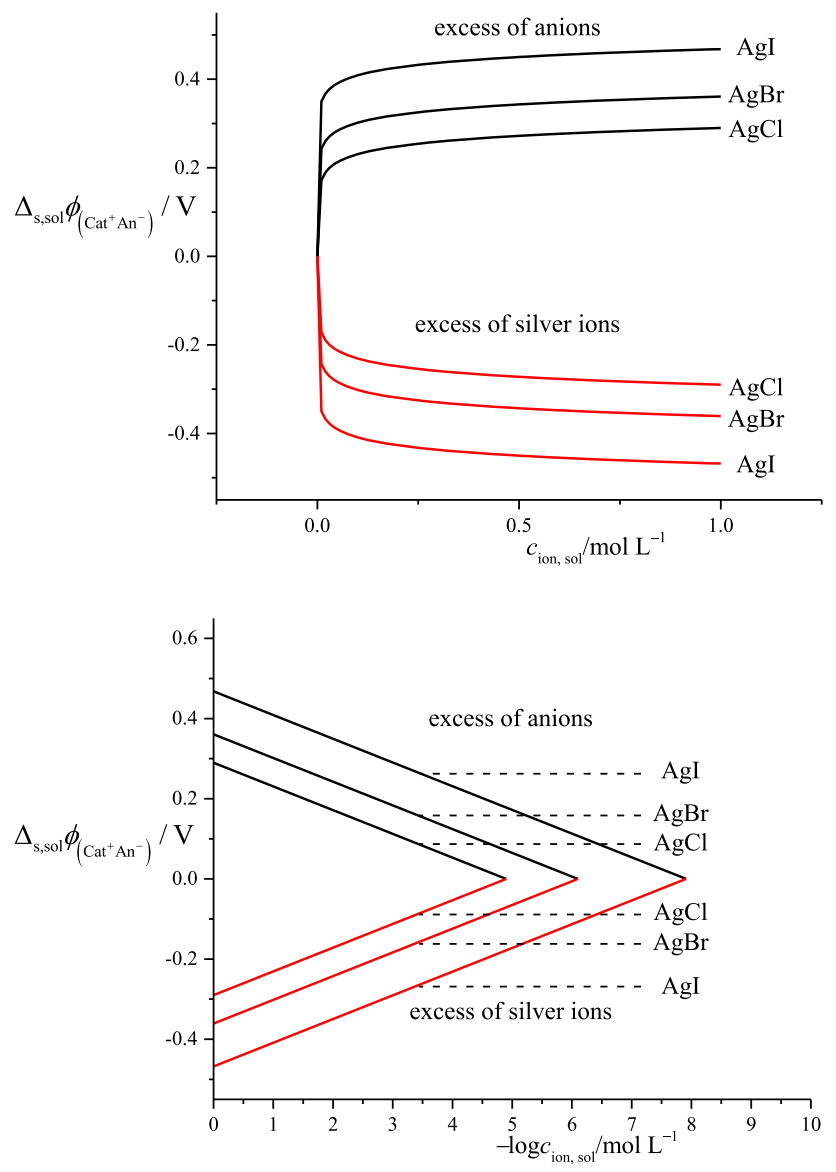

Fig. 6 Top: dependence of the potential difference at the saltlsolution interface $\Delta_{\mathrm{s}, \mathrm{sol}} \phi_{\left(\mathrm{Cat}^{+} \mathrm{An}^{-}\right)}=\phi_{\mathrm{sol},\left(\mathrm{Cat}^{+} \mathrm{An}^{-}\right)}-\phi_{\mathrm{s},\left(\mathrm{Cat}^{+} \mathrm{An}^{-}\right)}$on the concentration of added anions or cations in the solution. Bottom: same potential difference as function of the logarithm of concentration

i.e. the potential difference becomes negative. Figure 6 illustrates the dependencies (62) and (63) for the case of the silver halides $\mathrm{AgCl}, \mathrm{AgBr}$ and $\mathrm{AgI}$. Since the interfacial potential difference is defined as $\Delta_{\mathrm{s}, \mathrm{sol}} \phi_{\left(\mathrm{Cat}^{+} \mathrm{An}^{-}\right)}=$ $\phi_{\mathrm{sol},\left(\mathrm{Cat}^{+} \mathrm{An}^{-}\right)}-\phi_{\mathrm{s},\left(\mathrm{Cat}^{+} \mathrm{An}^{-}\right)}, \quad$ a positive sign of $\Delta_{\mathrm{s}, \mathrm{sol}} \phi_{\left(\mathrm{Cat}^{+} \mathrm{An}^{-}\right)}$means a negatively charged surface of the silver halides with respect to solution, and vice versa. In the case of titrations of halides with silver ions, the sign of $\Delta_{\mathrm{s}, \mathrm{sol}} \phi_{\left(\mathrm{Cat}^{+} \mathrm{An}^{-}\right)}$changes at the equivalence point. Before the equivalence point $\Delta_{\mathrm{s}, \mathrm{sol}} \phi_{\left(\mathrm{Cat}^{+} \mathrm{An}^{-}\right)}$has a positive sign, i.e. the solid $\mathrm{AgX}$ is negatively charged. After the equivalence point, when silver ions are in excess, $\Delta_{\mathrm{s}, \mathrm{sol}} \phi_{\left(\mathrm{Cat}^{+} \mathrm{An}^{-}\right)}$has a negative sign, i.e. the surface of the silver halides is positively charged. This is used in the Fajans methods [18-20] of indication using adsorption indicators, where, as an example, fluorescein anions are used as they are adsorbed on the positively charged surface of silver halides. The adsorption changes the colour of the silver halide precipitate, which serves as indication of the equivalence point. In Fig. 6 deviations between concentrations and activities are not taken into account.

At this point, it is interesting to note the similarities of the solid salt|solution interface with the processes underlying the function of the glass electrode: whereas in the case of the silver halides, the cations and anions are capable of partitioning, in the case of the glass electrode, only the cations, i.e. the protons, can partition and the anions, $i$. e. the "surface silicate groups", are unable to partition because they are immobile. This results in the well-known $\mathrm{pH}$ response of the Galvani potential difference at glasssolution interfaces [21-23].

\section{Conclusions}

In this lecture text the partition of salts between two immiscible solution phases is presented, and the equation describing the Galvani potential difference across the liquidlliquid interface is derived. The meaning of standard potentials of transfer of single ions from one solution phase to the other is discussed on the basis of an extrathermodynamic assumption. Further, some experimental details of the determination of the standard potentials of ions are mentioned. Finally, the equilibrium of a solid salt phase with its saturated solution phase is presented on the basis of ion partition equilibria, and the resulting surface charge of the solid phase is discussed in connection with adsorption indicators.

In this text, the structure of the double layers at the interfaces could not be considered.

Acknowledgements Open Access funding provided byProjekt DEAL. We are very thankful for many helpful suggestions provided by PD. Dr. Gudrun Scholz, Nico Heise, Javier Roman Silva, and Karuppasamy Dharmaraj.

Open Access This article is licensed under a Creative Commons Attribution 4.0 International License, which permits use, sharing, adaptation, distribution and reproduction in any medium or format, as long as you give appropriate credit to the original author(s) and the source, provide a link to the Creative Commons licence, and indicate if changes were made. The images or other third party material in this article are included in the article's Creative Commons licence, unless indicated otherwise in a credit line to the material. If material is not included in the article's Creative Commons licence and your intended use is not permitted by statutory regulation or exceeds the permitted use, you will need to obtain permission directly from the copyright holder. To view a copy of this licence, visit http://creativecommons. org/licenses/by/4.0/.

\section{References}

1. Nernst W (1891) Verteilung eines Stoffes zwischen zwei Lösungsmitteln und zwischen Lösungsmittel und Dampfraum. 
(Partition of a substance between two solvents and between the solvent and gas). Z Phys Chem (Leipzig) 8:110-139

2. Burgot J-L (2019) Understanding Lewis activities. ChemTexts 5:16

3. Láng G (2015) Basic interfacial thermodynamics and related mathematical background. ChemTexts 1:16

4. Inzelt $\mathrm{G}$ (2014) Crossing the bridge between thermodynamics and electrochemistry. From the potential of the cell reaction to the electrode potential. ChemTexts 1:2

5. Grunwald E, Baughman B, Kohnstam G (1960) The solvation of electrolytes in dioxane-water mixtures, as deduced from the effect of solvent change on the standard partial molar free energy. J Am Chem Soc 82:5801-5811

6. Scholz F, Kahlert H (2019) Chemical equilibria in analytical chemistry. The theory of acid-base, complex, precipitation and redox equilibria. Springer Nature, Chur, pp 142-145

7. de Namor AFD, Pugliese A, Casal AR, Llerena MB, Aymonino PJ, Velarde FJS (2000) Phys Chem Chem Phys 2:4355-4360

8. Katsuta S, Wakabayashi H, Tamaru M, Kudo Y, Takeda Y (2007) J Solut Chem 36:531-547

9. Nernst W, Riesenfeld EH (1902) Ueber electrolytische Erscheinungen an der Grenzfläche zweier Lösungsmittel. (About electrolytic phenomena at the interface of two solvents). Ann Phys 313:600-608

10. Scholz F (2015) Voltammetric techniques of analysis-the essentials. ChemTexts 1:17

11. Koryta J, Vanysek P (1981) Electrochemical phenomena at the interface of two immiscible electrolyte solutions. In: Bard AJ (ed) Advances in electrochemistry and electrochemical engineering, vol 12. Wiley, New York, p 113

12. Girault HH, Schiffrin DJ (1989) Electrochemistry of liquid-liquid interfaces. In: Bard AJ (ed) Electroanalytical chemistry, vol 15. Marcel Dekker, New York, pp 1-141

13. Kakiuchi T (1996) Equilibrium electric potential between two immiscible electrolyte solutions. Liquid-liquid interfaces. Theory and methods. CRC, Boca Raton, pp 1-17
14. Vanýsek P (1985) Electrochemistry on liquid/liquid interfaces. In: Lecture notes in chemistry, vol 39. Springer, Berlin

15. Scholz F, Komorsky-Lovrić Š, Lovrić M (2000) A new access to Gibbs free energies of transfer of ions across liquid-liquid interfaces and a new method to study electrochemical processes at well-defined three-phase junctions. Electrochem Commun 2:112-118

16. Scholz F, Gulaboski R (2005) Determination of Gibbs energies of ion transfer across water/organic liquid interfaces with threephase electrodes. ChemPhysChem 6:16-28

17. Scholz F, Doménech-Carbó A (2019) The thermodynamics of insertion electrochemical electrodes-a team play of electrons and ions across two separate interfaces (minireview). Angew Chem Int Ed 19:3279-3284

18. Kolthoff IM (1935) Adsorption indicators. Chem Rev 16:87-98

19. Fajans K (1938) Adsorption indicators for precipitation titrations. In: Brennecke E, Furman NH, Stamm H, Lang R, Fajans K, Böttger W (eds) Newer methods of volumetric chemical analysis. Tranlated by RE Oesper. Chapman and Hall, London, pp 201250. https://archive.org/stream/newermethodsofvo031798mbp\# page/n219/mode/2up. Accessed 22 Mar 2020

20. Pungor E, Schulek E (1972) Adsorption indicators. In: Bishop E (ed) Indicators. Pergamon, Oxford, pp 437-468

21. Scholz F, Kahlert H (2019) Chemical equilibria in analytical chemistry. Springer Nature, Cham, pp 230-233

22. Scholz F (2011) Nikolsky's ion exchange theory versus Baucke's dissociation mechanism of the glass electrode. J Solid State Electrochem 15:67-68

23. Scholz F (2011) From the Leiden jar to the discovery of the glass electrode by Max Cremer. J Solid State Electrochem 15:5-14

Publisher's Note Springer Nature remains neutral with regard to jurisdictional claims in published maps and institutional affiliations. 